\section{BAKACSI Gyula}

\section{A GLOBE-KUTATÁS \\ KULTÚRAVÁLTOZÓINAK VIZSGÁLATA FAKTORANALÍZIS SEGÍTSÉGÉVEL} A szervezeti kultúraváltozók nem függetlenek egymástól. A tanulmány a GLOBE társadalmi kultúra,
társadalmi értékek és a kettó különbségéból képzett differenciaváltozók faktoranalízisével kísérel meg fötársadalmi értékek és a kettó különbségéból ké

Kulcsszavak: Globe-kutatás, kultúraváltozók

A kultúrával kapcsolatos szakirodalmat olvasva két egymásnak látszólag ellentmondó jelenség - tủnhet fel az olvasónak: egyfelól a kultúraváltozók körének szerteágazósága (,burjánzása”), másfelól néhány olyan értékorientáció (alapvető hiedelem), amelyek önmagukban elégségesek a kultúrák közötti alapvetố különbségek megragadására, és amelyekre az elóbb emlîtett kultúraváltozók visszavezethetôk, tulajdonképpen azok részletezô kibontásainak, finom részváltozóinak tekinthetók. Az is megfigyelhetó, hogy bizonyos változók más néven, és olykor kisebb-nagyobb mértékben más tartalommal (definícióval és mérési mód al) jelennek meg kiilönböző szerzóknól. Mindezek nal) jelo alapján megfogalmazhatjuk azt a hipotézist, hogy szakirodalomban fellelhetố nagyszámú kultúraváltozó nem független egymástól, visszavezethetó néhány gyökérváltozóra, illetve egy faktoranalízis segítségével néhány fó faktorba rendezhetố. A fő faktorba rendezhetóség hipotézisét természetesen csak az azonos kutatás program)ban, azonos mintán elvégzett empirikus vizsgálatok esetében tudjuk igazolni vagy cáfolni. Tanulmányomban erre teszek kísérletet a GLOBE-kutatás változóinak faktoranalízisével.

\section{A GLOBE-kultúra értelmezése és kultúraváltozó}

A GLOBE kutató közösségének kultúraértelmezése az alábbiak szerint foglalható össze:

„A kultúra a közösség tagjainak közös tapasztalatokból származó és generációkon keresztü atöröklódő, a közösség valamennyi tagja által seinek, identitásainak és a lényeges események közös értelmezéseinek vagy jelentéseinek összessége." (House et al., 2004: 15. old.)

A fenti általános alapdefiníció mellett lényeges rámutatni a GLOBE figyelemre méltó módszertani újJonságára Míg a korábbi nemzetközi összehasolító kultúrakutások jellemzón lé́ń dimenziok mérték és értelmezték a kultúrák egymúśl vón seit, és azt vizsgálták, ,,ahogy a dolgok vannak", addig a GLOBE ezen kategória mellett (AS IS dimenziók) bevezeti a normatív (előíró) dimenziók (SHOULD BE) fogalmát is, melyek a megkérdezettek azon elvárását tükrözik, ,ahogy a dolgoknak lenniük kellene”. Ezáltal lehetôség van nemcsak a megkérdezettek által érzékelt, hanem a véleményük szerint kívánatos nemzeti és szervezeti kultúrák mérésére is.

Ezért a fenti általános kultúradefinícióra alapozva House - Wright - Aditya (1997) kétféle értelmezési lehetőséget lát a kultúra meghatározására.

Az 1. értelmezés a kultúra normatív megközelítése: A kultúra a közösség megkülönböztetó jellemójje, tagjai pszichológiai jellemzóinek olyan közös mintázata, amely modellként szolgál, meghatározó érzelmi, beállitódásbéli (attitudinális) és magatartási irányultságot eredményez, amely a közösséget megkülönböztethetôvé teszi más köáthagyományozódik" (House - Wright - Aditya, 1977: 539-540. old.). osztott motivációinak, értékeinek, meggyózódézösségektól, és amely generációról generációra
Ebben a megközelítésben tehát a kultúra olyan más közösségektól világosan megkülönböztethetó normatív rendszer, lelki-pszichológiai közösség, melynek tagja bizonyos közös értékeket, hiedelmeket vallanak, közos elófeltevéseket, és ezen alapuló közös jelentés- és valóságinterpretációkat osztanak, és a közös normarendszer alapján kialakult modellértékú viselkedésmintákat követnek, amelyekhez ragaszkodnak. Ezek a közös(ségi) kódok, válaszok nem jobbak vagy rosszabbak, mint más közösségek kódjai, válaszai, csak jellegzetesen mások.

A normatív kultúraértelmezésnek van azonban egy komoly hátulütóje, mégpedig az, hogy mivel igen nehéz arra vonatkozó standardokat meghatározni, hogy az előfeltevések, hiedelmek, értékek, jelentésinterpretációk, azonosságtudat és motivációk milyen szintú azonosságától állíthatjuk azt, hogy egy közösség tagjai azonos kultúrához tartoznak - az ilyen módon értelmezett kultúr igen nehéz közvetlenül, konkrét formában megragadn mérni, operacionalizálni. A kultúra normatív értelmezésé más szakirodalmi források kinyilvánított, vallott értéke nek (espoused values) is nevezi (lásd pl. Argyris, 1992).

A 2. értelmezés a kultúra tapasztalati megközelítése: „A kultúra a közösség közösen osztott értelmezéssel és értékekkel jellemezhetó megkülönböztetö környezete, amely modellként szolgáló meghatározó érzelmi, beállitódásbéli (attitudinális) és magatartási irányultságot eredményez, amely közösséget megkülönböztethetóvé teszi más közösségektól, és amely generációról generációra áthagyományozódik."2 (House - Wright - Aditya 1977: 540. old.).

Ebben a megközelítésben tehát a kultúra a tagjatól (de a kutatótól is) független, amelyet a közvetlen vizsgálható, megragadható, viselkedesben, tárgyiasult környezetben megtestesült megkülönböztetố közösségi tapasztalatokban érhetünk tetten. A kultúra tapasztala (leíró) megközelítése tehát kevésbé tekinthető kinyilatkoztatott, kinyilvánított és szubjektív véleménynek, hiedelemnek, elófeltevésnek, észlelésnek, interpretácioténynek, amely a közös történelmi múltben a közö̈ténynek, ame a a közös ségre jellenzo fizikai-tárgyi könyezetben (szimbólu-

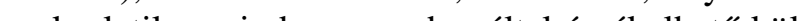
gyakorlatilag minden az ember által érzékelhetố küls korulmenyben ölt testet.

A kultúra leíró-tapasztalati értelmezését más szakirodalmi források követett értékeknek (theory-in-use) nevezik (lásd pl. Argyris, 1992).

A kultúra kétféle értelmezésének viszonyára úgy tekinthetünk, mint ugyanazon érem két oldalára. A történelem során a legtöbb közösség lényegében ugyanazokkal külső hatásokkal és belső problémákkal szembesültt, legfeljebb ezek az adott közösség fejlettségi szintjétól függóen más sorrendben, illetve más-más korszakban következnek be. A kultúrák között azonban nem a környezeti hatások, hanem az azokra adott közös(ségi) válaszok alapjan tehetünk különbséget. Egy közösség elvileg többféle sikeres választ adhat az oót ért kơrnyezeti hatásokra, gyakorlatilag azonban meg kell találnia egy konkrét választ, amellyel biztosítja fennmaradását, túlélését, növekedését, fejlődését. Ezt a sikeres alkalmazkodási mintát aztán normaként (sikeres alkalmazkodási technikaként) örökíti tovább a közösś́ en belïl A kultúra tapasztabtíntelmezése tehát nem más vetlenil vizsélható, vetlenu vizsgálicho lekvésben, illetve szimbolumokban, tárgyiasult megtestesülési formában jelentkezó alakja. A normatív értelmezés a kultúra tagjainak szubjektumában létezik: az ezt alkotó elemek - értékek, normák, előfeltevések - valójában sokkal inkább következményei a kultúrának, semmint meghatározó sajátosságai. A leíró értelmezés tehát maga a múltbeli és jelenbéli környezeti és belsố kihívásokra adott válasz, amelynek elsajátítása a közösség fennmaradását és fejlődését biztosítja, míg a normatív kultúraértelmezés azt a sikeres alkalmazkodási mintát mutatja fel, amely közös normatív irányultsácként (viselkedésbeli, magata tásbeli és attitúdbeli elvárásként, normaként) nemzedétás ne és a

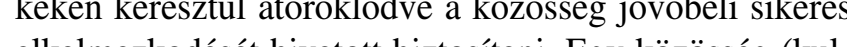
aka túra) mindketto alapján világosan megkulônbozztethetố más kozôssségektố. Egy adott kôzôsségre jellemzö min a jelen kihívásaira adott válaszokat jelentố ténylegesen követett gyakorlata, mind a normatív módon átörökített, szubjektumban létezó értékrendszere. A GLOBE-kutatás 2004-ben publikált átfogó monográfiájában a kétféle kultúraértelmezés megnevezését konzekvensen ennek megfelelően alakították ki (House et al., 2004): a tapasztalati értelmezést gyakorlatnak (practices), a normatív értelmezést pedig értéknek (values) nevezik.

A kultúra kétféle értelmezésére a szakirodalomban használt eltérô terminológiák, kifejezések viszonyát az 1. táblázat mutatja be.

kétféle kultúraértelmez

1. táblázat különféle elnevezéseinek viszon

\begin{tabular}{|c|c|c|c|}
\hline $\begin{array}{c}\text { Globe } \\
\text { (2004) }\end{array}$ & \multicolumn{2}{|c|}{ Több szakirodalmi forrás } & Argyris (1992) \\
\hline $\begin{array}{l}\text { gyakorlat } \\
\text { (practices) }\end{array}$ & $\begin{array}{c}\text { tapasztalati } \\
\text { (experiential) }\end{array}$ & $\begin{array}{c}\text { léró } \\
\text { (descriptive) }\end{array}$ & $\begin{array}{l}\text { követett értékek } \\
\text { (theory-in use) }\end{array}$ \\
\hline $\begin{array}{c}\text { értékek } \\
\text { (values) }\end{array}$ & $\begin{array}{c}\text { normatív } \\
\text { (normative) }\end{array}$ & $\begin{array}{c}\text { elóíŕ́ (prescriptive, } \\
\text { proscriptive) }\end{array}$ & $\begin{array}{c}\text { vallott értékek } \\
\text { (espoused values) }\end{array}$ \\
\hline
\end{tabular}


A GLOBE kutatás a nemzeti és szervezeti kultúrát - azok tapasztalati (gyakorlat) és normatív (érték) értelmezését - kilenc dimenzió (hatalmi távolság, bizonytalanságkerülés, kollektivizmus I. - intézményi kollektivizmus, kollektivizmus II. - csoportkollektivizmus, nemi egyenlőség, rámenősség/asszertivitás, teljesítményorientáció, jövőorientáció, humánorienaz ismert empirikus kultúrakutatási elózmények szinte minden lényeges kultúraváltozóját, sốt azokat újakkal zzonosság mellett azonban utalunk arra hogy kisebbazonossag mélt az nagyobb métcék a Ami a válozok méce a valloźk mécséce ede legyenek képesek minél pontosabban és megbízhatóbban kimutatni.

E kultúraváltozók (dimenziók) meghatározásait GLOBE monográfiája (House et al., 2004: 12-13. old ) alapján mutatom be.

- hatalmi távolság (Power Distance): annak a mértéke, hogy egy szervezet vagy a társadalom tagjai mennyire váriák el és fogadják el a hatalon

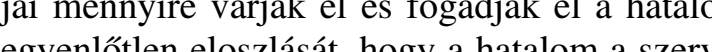
egyenolon eloszlasit, hogy a halom a szervejön, és oda koncentrálódjon,

bizonytalanságkerülés (Uncertainty Avoidance): annak a mértéke, hogy egy szervezet vagy a tár sadalom tagjai kialakult társas normákra, rituálékra és bürokratikus gyakorlatra támaszkodva mennyire törekszenek a bizonytalanság elkerulésére, mérsékelve ezzel a jövőbeli események elörejelezhetetlenségét. Institutional collectivism): annak a mértéke, hogy a szervezetek és a társadalom intézményi norm és gyakorlata mennyire bátorítják és jutalmazzák cselekvést,

csoportkollektivizmus (Collectivism II. - InGroup collectivism): annak a mértéke, hog az egyenenek szervezetükben vagy családjukban mennyire juttatják kifejezésre büszkeségüket, lojalitásukat és összetartozás-érzésüke

nemi egyenlóség (Gender egalitarianism): annak mértéke, hogy a társadalom vagy egy szerveze különbségeket, elósegítve ezzel a nemek közötr egyenlőséget, táció) alapján mérte. A választott dimenziók felölelik egészítik ki. A változók terén tapasztalható fogalmi ki és validált, amelyeknek első́dleges célja az, hogy a kulturrák közotti eltêréseket, külonnbségeket (varianciát) zet vagy komány mán

intézményi kollektivizmus (Collectivism I. mennyire minimalizálja a nemi szerepek közt

rámenósség/asszertivitás (Assertiveness): annak mértéke, hogy az egyének társas kapcsolataikban mennyire határozottak (asszertívek), szembenállóak (konfrontatívak) és agresszívek szervezeteikben vagy a társadalomban,

- teljesítményorientáció(Performance orientation): annak a mértéke, hogy egy szervezet vagy a társadalom mennyire bátorítja a csoporttagokat a teljesítmény növelésére és a kiválóságra, és mennyire jutalmazza ôket ezért,

- jövóorientáció (Future orientation): annak mértéke, hogy egy szervezt vagy a tárad alo mérmilyen ege

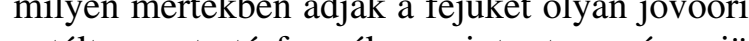

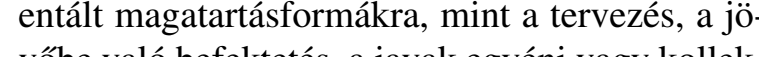
vobe való befektetés, a javak egyéni vagy kollektiv felélésének elhalasztása

humánorientáció (Human orientation): annak a mértéke, hogy a szervezetek vagy a társadalom tagjai mennyire bátorítanak és jutalmaznak másokat arra, hogy igazságosak, méltányosak, önzetlenek, barátságosak, nagylelkúek, gondoskodók és kedvesek legyenek.

\section{A társadalmi gyakorlat (leíró) változók közötti} kapcsolat (fó faktorok)

A GLOBE kutató közössége a fenti kultúraváltozókat úgy tekinti, mint amelyek együttesen képesek a kultúrák közötti érdemi különbségtételre. A GLOBE kutatás céljára kialakított változók ugyanakkor statisztikai értelemben nem függetlenek egymástól, a 62 kultúrára kiterjedô mérés adott társadalmakra jellemző átlag értékeit figyelembe véve bizonyos változók korrelációt mutatnak egymással.

Atársadalmi szintú gyakorlatot tükröző (tapasztalati, leíró) változók közötti korrelációt lásd a 2. táblázatban. A keresztkorrelációs tábla a GLOBE-kultúraváltozók közötti összefüggések sajátos mintázatára világít rá.

Hat olyan társadalmi gyakorlatot tükröző kultúraváltozó van, amelyek között páronként (két kivétellel) erős és szignifikán korréćció mutatkozik: cso-

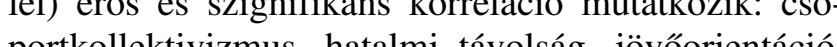
poizontón tézményi kollektivizmus (ezek közül azociós és inportkolektivizmusna a teljeśtményal azonban a csoportkollektivizmusnak a teljesítményorientációval és az intézményi kollektivizmussal csak gyenge és nem szignifikáns a korrelációja). Érdemes ugyanakkor felfigyelni arra, hogy a fenti hat kultúraváltozó közül kettố (a csoportkollektivizmus és a hatalmi távolság) erős és szignifikáns negatív korrelációt mutat a többi néggyel, amelyek ugyanakkor egymással erôs és szignifikáns pozitív korrelációt mutatnak. Az intézményi kollekti-

VEZETÉ STUDOMÁNY vizmus ugyanakkor erôs és szignifikáns korreláció mutat a rámenősség/asszertivitás és a humánorientáció változókkal. A nemi egyenlőség társadalmi gyakorlat pedig nem mutat érdemi korrelációt egyetlen tovább társadalmigyakorlat-valtozóval sem (illetve a hatalmi távolsággal és a teljesítményorientációval rendre kimutatható egy közepesen erős, $\mathrm{p}<.05$, szinten szignifikán negatív korrelációs kapcsolata).

tán) a 3. táblázat mutatja be a faktoranalízis eredményeként kapott 3 fófaktort. Ez a faktorstruktúra nagymértékben megerôsíti a 2. táblázatban megfigyelhetố igen összetett korrelációs hálót

A kapott három főfaktor a teljes minta varianciájának $72 \%$-át magyarázza.

A 3. táblázatból kitúnik, hogy a kilenc dimenzióból:

2. táblázat

A GLOBE társadalmi gyakorlat (leíró) változói közötti korrelációk (n=61)

\begin{tabular}{|c|c|c|c|c|c|c|c|c|c|}
\hline & 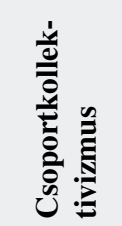 & 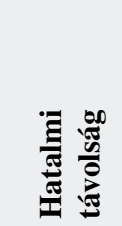 & 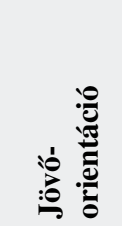 & 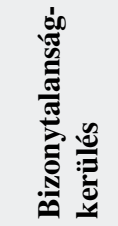 & 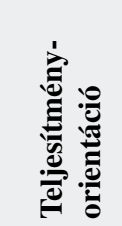 & 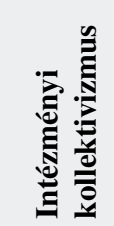 & 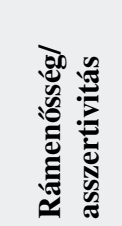 & 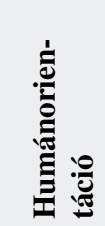 & 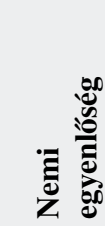 \\
\hline Csoportkollektivizmus & 1 & $0,55^{* *}$ & $-0,44 * *$ & $-0,60 * *$ & $-0,11$ & $-0,19$ & 0,09 & $0,32 *$ & $-0,2$ \\
\hline Hatalmi távolság & $0,55^{* *}$ & 1 & $-0,52 * *$ & $-0,50^{* *}$ & $-0,36^{* * *}$ & $-0,44 * *$ & 0,17 & $-0,14$ & $-0,30^{*}$ \\
\hline Jövőorientáció & $-0,44^{* * *}$ & $-0,52^{* * *}$ & 1 & $0,76 * *$ & $0,63 * *$ & $0,46 * *$ & 0,07 & 0,06 & $-0,06$ \\
\hline Bizonytalanságkerülés & $-0,60$ ** & $-0,50^{* *}$ & 0,76 ** & 1 & $0,58^{* *}$ & 0,40 ** & $-0,07$ & $-0,01$ & $-0,06$ \\
\hline Teljesítményorientáció & $-0,11$ & $-0,36^{* *}$ & $0,63^{*}$ & $0,58^{* *}$ & 1 & $0,43 * *$ & 0,05 & 0,25 & $-0,31$ * \\
\hline Intézményi kollektivizmus & $-0,19$ & $-0,44 *$ & $0,46 * *$ & $0,40^{* * *}$ & $0,43 * *$ & 1 & $-0,42 * *$ & $0,43 * *$ & $-0,01$ \\
\hline Rámenősség/asszertivitás & 0,08 & 0,16 & 0,07 & $-0,07$ & 0,06 & $-0,42 * *$ & 1 & $-0,40^{*}$ & $-0,08$ \\
\hline Humánorientáció & $0,32 *$ & $-0,15$ & 0,07 & 0 & 0,25 & $0,43 * *$ & $-0,40 * *$ & 1 & $-0,15$ \\
\hline Nemi egyenlőség & $-0,2$ & $-0,30^{*}$ & $-0,06$ & $-0,06$ & $-0,31 *$ & $-0,01$ & $-0,08$ & $-0,15$ & 1 \\
\hline
\end{tabular}

$*(\mathrm{p}<.05)$ szinten szignifikáns, ** $(\mathrm{p}<.01)$ szinten szignifikáns

A kilenc társadalmigyakorlat-változóra ezek után egy faktoranalízist lefuttatva (fókomponens-elemzés, Varimax Kaiser-módszerrel, rotációval - 5 iteráció

öt változó - nemi egyenlőség, jövőorientáció, bizonytalanságkerülés, asszertivitás/rámenôsség és a humánorientáció - rendelhetổ hozzá egyértelmúen valamely faktorho

- a „,sak a >0,25 feletti faktorsúlyokat vesszük fi-

3. táblázat

A GLOBE társadalmi gyakorlat (leíró) változói faktoranalízisének eredménytáblája

\begin{tabular}{|c|c|c|c|c|c|c|}
\hline Rotated Component Matrix(a) & \multicolumn{3}{|c|}{ Raw } & \multicolumn{3}{c|}{ Rescaled } \\
\hline $\begin{array}{c}\text { Extraction Method: Principal Component Analysis. } \\
\text { Rotation Method: Varimax with Kaiser Normalization. }\end{array}$ & \multicolumn{3}{|c|}{ Component } & \multicolumn{3}{c|}{ Component } \\
\hline (a) Rotation converged in 5 iterations. & 1 & 2 & 3 & 1 & 2 & 3 \\
\hline Hatalmi távolság &,- 241 &,- 131 &, 163 &,- 591 &,- 321 &, 400 \\
\hline Csoportkollektivizmus (Triandis) &,- 467 &, 142 &, 518 &,- 640 &, 195 &, 710 \\
\hline Teljesítményorientácí́ &, 293 &, 075 &, 191 &, 717 &, 183 &, 467 \\
\hline Jövóorientácí́ &, 409 &, 027 &, 055 &, 884 &, 059 &, 118 \\
\hline Bizonytalanságkerülés &, 566 &, 004 &,- 028 &, 936 &, 006 &,- 046 \\
\hline Intézményi kollektivizmus &, 200 &, 291 &,- 015 &, 471 &, 687 &,- 035 \\
\hline Rámenóssé́g/asszertivitás &, 012 &,- 258 &, 128 &, 031 &,- 695 &, 344 \\
\hline Humánorientácí́ &,- 006 &, 404 &, 128 &,- 012 &, 857 &, 271 \\
\hline Nemi egyenlóś́g &,- 049 &, 025 &,- 216 &,- 134 &, 068 &,- 587 \\
\hline
\end{tabular}

VEZETÉSTUDOMÁNY

XLIII. ÉVF. 2012. 4. SZÁM / ISSN 0133-0179 
gyelembe" szabályt alapul véve ugyanakkor négy változó - a csoportkollektivizmus (Triandis), hatalmi távolság, a teljesítményorientáció és az intézményi kollektivizmus - rendre két faktoro „,ül rajta” (a faktoranalízis „tolvajnyelvén” két faktorra töltenek).

Az a széles körben alkalmazott fó szabály itt nem alkalmazható, mely szerint, ha egy változó két faktorra tölt, de a faktorsúlyok közötti különbség meghaladj a kétszerest, az egyértelmúen eldönti az adott változó fókomponenshez (fó faktorhoz) tartozását, mivel a faktorsúlyok közötti különbség sehol sem éri el a kétszerest. A fenti négy változó hovatartozásának eldöntésekor ezért azt az egyszerú szabályt követem, hogy a(z abszolút értékben) nagyobb faktorsúly dönti el a fô faktorhoz tartozást. Elemzésemben ugyanakkor foly matosan utalunk az erôs, másodlagos töltésre.

A 4. táblázat alapján - és a fenti szabályok figyelembevételével - az alábbi három fô faktort (fố komponenst) azonosíthatjuk:

1. számú fő faktor: Fejlesztésorientáltság vs Status quo orientáltság,

2. számú fő faktor: Versengés vs. Kooperáció,

3. számú fố faktor: Tekintélyelvú vs. Független

(independens) kultúra.

\section{1. számú fó faktor: Fejlesztésorientáltság vs.}

Status quo orientáltság

A fó faktorba sorolt kultúraváltozók: bizonytalanságkerülés - jövőorientáció - teljesítményorientáció hatalmi távolság (negatív faktorsúllyal).

A fố faktorra másodlagosan töltő kultúraváltozók: intézményi kollektivizmus - csoportkollektivizmus (negatívan).

A fő faktor a variancia $35 \%$-át magyarázza.

f'ó faktor értelmezése:

- Bizonyos kultúrák a bizonytalanság fölötti kontrollra, a jövő előrejelezhetôségére és tervezésére törekszenek, jövő́- és teljesítményorientáltak, és nem tolerálják a hatalom túlzottan egyenlő́tlen elosztását. Ezeket összefoglalóan fejlesztésorientált ${ }^{3}$ kultúráknak nevezhetjük.

Más kultúrákra inkább a nagyobb bizonytalanságérzet jellemzó, jelenbeli problémák megoldására koncentrálnak, kevésbé jellemzô a kiemelkedố teljesítményre való törekvés, vagy annak megléte esetén nem a kiválóság a jutalmazás és elómenetel alapja, ugyanakkor relatíve magasabb hatalmi távolság, és ennek elfogadottsága jellemzi a társadalmi viszonyaikat. Ezeket a kultúńkat jelenben 4. táblázat

A GLOBE társadalmi gyakorlat (leíró) változóinak három fơ faktorba rendezôdése

\begin{tabular}{|l|c|c|c|c|c|c|}
\hline \multirow{2}{*}{} & \multicolumn{3}{|c|}{ Raw } & \multicolumn{3}{c|}{ Rescaled } \\
\cline { 2 - 7 } & \multicolumn{3}{|c|}{ Component } & \multicolumn{3}{c|}{ Component } \\
\cline { 2 - 7 } & 1 & 2 & 3 & 1 & 2 & 3 \\
\hline Bizonytalanságkerülés &, 566 & & &, 936 & & \\
\hline Jövóorientáció &, 409 & &, 055 &, 884 & &, 118 \\
\hline Teljesítményorientáció &, 293 &, 075 &, 191 &, 717 &, 183 &, 467 \\
\hline Hatalmi távolság &,- 241 &,- 131 &, 163 &,- 591 &,- 321 &, 400 \\
\hline Humánorientáció & &, 404 &, 128 & &, 857 &, 271 \\
\hline Rámenósség/asszertivitás & &,- 258 &, 128 & &,- 695 &, 344 \\
\hline Intézményi kollektivizmus &, 200 &, 291 & &, 471 &, 687 & \\
\hline Csoportkollektivizmus &,- 467 &, 142 &, 518 &,- 640 &, 195 &, 710 \\
\hline Nemi egyenlósége &,- 049 & &,- 216 &,- 134 & &,- 587 \\
\hline
\end{tabular}

Alább mind a három fő komponenst (fő faktort) röviden bemutatom, a következó szempontrendszer szerin - mely GLOBE-változók alkotják a fó faktort, - mely GLOBE-változók töltenek másodlagosan az adott fő faktorra,

- a fő faktor a variancia hány \%-át magyarázza,

- a fő faktor értelmezése, a megnevezés rövid magyarázata.
Ha a fó faktorok értelmezésébe a másodlagosan arra töltó változókat is bekapcsoljuk, a fejlesztésorientált kultúrára inkább jellemzố a szélesebb társadalmi közegben kooperáló (intézményi kollektivista) gondolkodás, míg a orientált kultúrában jellemzóbb a szúkebb közeghez való erôsebb ragaszkodás, az azon belül kialakított kooperatív szúkebb közösségéhez való kötődése, lojalitása, büszkesége relatíve alacsonyabb. Ezzel szemben a status quo stratégiák (többgenerációs családi minta, kaláka), míg a szélesebb társadalmi közegben az önérdekvezérelt, de-

\section{2. számú fö faktor: Versengés vs. Kooperáció}

A fő faktorba sorolt kultúraváltozók: humánorientáció - rámenősség/asszertivitás (negatív faktorsúllyal) - intézményi kollektivizmus.

A fő faktor a variancia közel 21\%-át magyarázza.

A fó faktor értelmezése:

- Bizonyos kultúrák humánorientáltak, gondoskodóak (kerülik az asszertív, rámenôs viselkedés mintákat) és a szélesebb társadalmi közegbe integrálódó, kollektív viselkedési stratégiák jellemzik). Ezeket összefoglalóan kooperatív kultúráknak nevezhetjük.

Más kultúrákra ugyanakkor a rámenósebb, asszertívabb viselkedésminták, a gondoskodás, igazságosság, méltányosság, önzetlenség, nagylelkűség hiannya és az egyéni boldogulási stratégiákat követô, önérdeket előtérbe helyező gondolkodás és cselekvés jellemző. Ezeket a kultúrákat versengó kultúráknak nevezhetjük.

\section{3. számú fö faktor: Tekintélyelvü vs. Független} (independens) ${ }^{5}$ kultúra

A fö faktorba solt kultúraváltozók: csoportkollektivizmus - nemi egyenlőség (negatív faktorsúllyal). fenzív, individualista cselekvésre támaszkodás.

A fő faktorra másodlagosan töltő kultúraváltozók: teljesítményorientáció - hatalmi távolság.

A fó faktor a variancia 16\%-át magyarázza.

A fó faktor értelmezése:

- Bizonyos kultúrákra jellemzó, hogy a nemekre jellemző szerepek nem, vagy nehezen átjárhatóak, a társadalmi munkamegosztásban elfoglalt helyünket eróteljesen meghatározza a nemek közti, születésünktól adott természetes biológiai munkamegosztás, a közösség tagjai ugyanakkor lojálisak szúkebb társas közegükhöz, és büszkék arra, hogy annak tagjai. Ezeket összefoglalóan tekintélyelvü (autoritásalapú, paternalisztikus) kultúráknak nevezhetjük

- Más kultúrákban a születéskor a nemekre jellemzô szerepek nem determinisztikusak, a társadalmi munkamegosztásban ezek a szerepek szabadon átjárhatóak, és a szí́kebb közösséghez füződő kötelékek relatíve lazábbak. Ezcket a

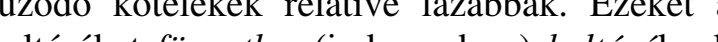
kulturákat fuggetlen (independens) kulturaknak
nevezhetjük.

Ha a fó faktorok értelmezésébe a másodlagosan arra töltố változókat is bekapcsoljuk, a tekintélyelvü (paternalisztikus) kultúrára jellemző a relatíve nagyobb hatalmi távolság és a teljesítményorientáció. Ezzel szemben a független (independens) kultúr kisebb hatalmi távolság, azaz erőteljes

5. táblázat

\section{A GLOBE társadalmi érték (normatív) változói közötti korrelációk}

$(\mathrm{n}=61)$

\begin{tabular}{|c|c|c|c|c|c|c|c|c|c|}
\hline & 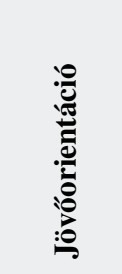 & 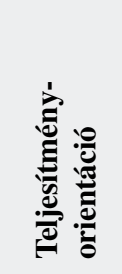 & 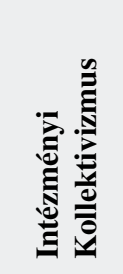 & 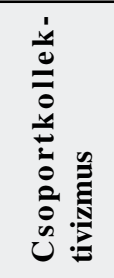 & 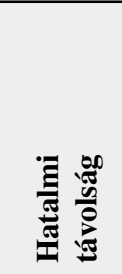 & 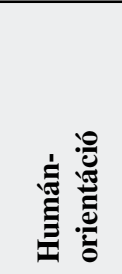 & 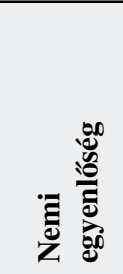 & 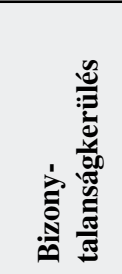 & 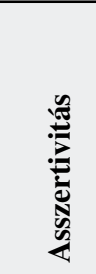 \\
\hline Jövőorientáció & 1 & $0,40^{* *}$ & $0,48^{* *}$ & $0,51 * *$ & $-0,06$ & $-0,11$ & $-0,36 * *$ & $0,64 * *$ & 0,09 \\
\hline Teljesítményorientáció & $0,40^{* * *}$ & 1 & $0,44 * *$ & $0,58^{* *}$ & $-0,39 * *$ & 0,06 & 0,22 & 0,15 & $-0,02$ \\
\hline Intézményi kollektivizmus & $0,48 * *$ & $0,44 * *$ & 1 & $0,29 *$ & $-0,31^{*}$ & $-0,13$ & $-0,04$ & $0,42 * *$ & $-0,21$ \\
\hline Csoportkollektivizmus & $0,51 * *$ & $0,58 * *$ & $0,29 *$ & 1 & $-0,22$ & $-0,15$ & 0,13 & $0,30^{*}$ & 0,01 \\
\hline Hatalmi távolság & $-0,06$ & $-0,39 * *$ & $-0,31^{*}$ & $-0,22$ & 1 & $-0,42 * *$ & $-0,49 * *$ & 0,17 & $0,30^{*}$ \\
\hline Humánorientáció & $-0,11$ & 0,06 & $-0,13$ & $-0,15$ & $-0,42 * *$ & 1 & 0,21 & $-0,18$ & $-0,11$ \\
\hline Nemi egyenlóség & $-0,36 * *$ & 0,22 & $-0,04$ & 0,13 & $-0,49 * *$ & 0,21 & 1 & $-0,55 * *$ & $-0,28 *$ \\
\hline Bizonytalanságkerülés & $0,64 * *$ & 0,15 & $0,42 * *$ & $0,30^{*}$ & 0,17 & $-0,18$ & $-0,55 * *$ & 1 & 0,2 \\
\hline Asszertivitás & 0,09 & $-0,02$ & $-0,21$ & 0,01 & $0,30 *$ & $-0,11$ & $-0,28^{*}$ & 0,2 & 1 \\
\hline
\end{tabular}

* $(\mathrm{p}<.05)$ szinten szignifikáns, ** $(\mathrm{p}<.01)$ szinten szignifikáns

\section{VEZETÉSTUDOMÁNY}

XLIII. ÉVF. 2012. 4. SZÁM / ISSN 0133-0179 
A GLOBE társadalmi érték (normatív) változói faktoranalízisének eredménytáblája án fón faktor

\begin{tabular}{|l|c|c|c|c|c|c|}
\hline \multirow{2}{*}{$\begin{array}{c}\text { Rotated Component } \\
\text { Matrix(a) }\end{array}$} & \multicolumn{3}{|c|}{ Raw } & \multicolumn{3}{c|}{ Rescaled } \\
\cline { 2 - 7 } & \multicolumn{3}{|c|}{ Component } & \multicolumn{3}{c|}{ Component } \\
\cline { 2 - 7 } & 1 & 2 & 3 & 1 & 2 & 3 \\
\hline Teljesítményorientáció &, 261 &,- 066 & &, 777 &,- 196 & \\
\hline Intézményi kollektivizmus &, 360 &, 104 &,- 161 &, 734 &, 213 &,- 329 \\
\hline Csoportkollektivizmus &, 256 & & &, 723 & & \\
\hline Jövőorientáció &, 268 &, 216 & &, 662 &, 533 & \\
\hline Hatalmi távolság &,- 181 &, 180 &, 074 &,- 518 &, 517 &, 213 \\
\hline Nemi egyenlóś́g &, 095 &,- 425 & &, 198 &,- 884 & \\
\hline Bizonytalanságkerülés &, 271 &, 503 & &, 448 &, 830 & \\
\hline Humánorientáción & &,- 075 & & &,- 296 & \\
\hline Asszertivitás & &, 139 &, 626 & &, 215 &, 968 \\
\hline
\end{tabular}
vételével, a többi értékváltozóval (a hatalmi távolság-
gal ugyanakkor erós és szignifikáns negatív korrelációs (participáció) jellemzi a teljesítményorientáció relatíve alacsonyabb mértéke mellett.

\section{A társadalmi érték (normatív) változók közötti} kapcsolat (fó faktorok)

A társadalmi szintú érték (normatív) változók között korrelációt lásd az 5. táblázatban.

A társadalmi értékeket tükrözố kultúraváltozók igen összetett kapcsolati hálóba rendeződnek. Három olyan változó van, amelynek további öt értékkel van erôs és szignifikáns korrelációja (a jövőorientáció, a hatalmi távolság, az intézményi kollektivizmus), és további három olyan változó, amelyeknek további néoy értékkel van erôs és szionifikáns korrelációja (teljesítményorientáció, csoportkollektivizmus, nemi egyenlósé́ bizonyto, csoponiís). Egyedül a humánenlosé bizonytalanságkeriess). Egyedil a humánorientáció társadalmi érték nem mutat érdemi korrelációt, egy kigal ugyanakkor erốs és szignifikáns negatív korreláciớ kapcsolatban áll)

A kilenc társadalmiérték-változóra egy faktoranalízist lefuttatva (fókomponens-elemzés, Varimax Kaisermódszerrel, rotációval - 6 iteráció után) a 6. táblázatban olvasható faktorstruktúrát kapjuk

A három komponens (fő faktor) összességében variancia 66\%-át magyarázza.

A 6. táblázatból kitûnik, hogy a kilenc változóból:

hat változó - a teljesítményorientáció, az intézményi kollektivizmus, a csoportkollektivizmus (Triandis), a nemi egyenlóség, a humánorientáció és az asszertivitás/rámenôsség - rendelhetố hozzá egyértelmúen valamely faktorhoz,

- három változó - a jövőorientáció, a hatalmi távolság és a bizonytalanságkerülés - ugyanakkor (a ,,ssak a >0,25 feletti faktorsúlyokat vesszük figyelembe" szabályt alapul véve) rendre két faktoron „ül rajta” (két faktorra töltenek).

A fó szabály (a faktorsúlyok közötti kétszeres küönbség) legfeljebb a bizonytalanságkerülés érték föfaktorhoz tartozását dönti el, viszonylag egyértelmúen. A jövőorientáció és a hatalmi távolság változó hovatartozásának eldöntésekor ismét azt az egyszerú szabályt követem, hogy a(z abszolút értékben) nagyobb faktorsúly dönti el a fó faktorhoz tartozást (ez azonban a hatalmi távolság esetében okoz fejtörést, hiszen itt az 1. és a 2. fó komponensekre való töltés (factor-load) abszolút értéke között csupán 0,001 különbség van).

A 6. táblázat alapján - és a fenti szabályok figyelembevételével - az alábbi három fő faktort (fő kompo-

1. számú foó faktor: Nem-zéró összegú (nyer/nyer) vs Zéróösszegú (nyer/veszít) ${ }^{6}$ kultúra,

2. számú fő́faktor: Konzervatív vs. Liberális ${ }^{7}$ kultúra,

3. számú főfaktor (egyetlen eredeti GLOBE változó

komponenssel): Asszertivitás.

Alább mind a három fó komponenst (fó faktort) röviden bemutatjuk, a következó egységes szempontrendszer szerint:

mely GLOBE-változók alkotják a fó faktort

- mely GLOBE-változók töltenek másodlagosan az adott fófaktorra,

- a fố faktor a variancia hány \%-át magyarázza,

- a fő faktor értelmezése, a megnevezés rövid magyarázata.

VEZETÉSTUDOMÁNY nenst) azonosíthatjuk:

\section{1. számú fö faktor:}

Nem-zéró osszegü (nyer/nyer) vs. Zéróösszegü

(nyer/veszit) kultúra

A fő faktorba sorolt kultúraváltozók: teljesítményorientáció - intézményi kollektivizmus - csoportkolektivizmus - jövőorientáció - hatalmi távolság elutasítása (a hatalmi távolság negatív faktorsúllyal).

A fő faktorra másodlagosan töltő kultúraváltozó: bizonytalanságkerülés.

A fő faktor a variancia 29\%-át magyarázza.

A fố faktor értelmezése:

- Bizonyos kultúrák kinyilvánított, szubjektív érték- és hiedelemrendszerükben hangsúlyosnak tekintik a kiválóságra való törekvést, kooperatív stratégiák követését mind közvetlen, szúkebb társas, mind szélesebb társadalmi közegükben, hangsúlyosnak tekintik a jövóbe tekintést, és elutasítva a hatalom egyenlôtlen elosztását, társadalmi viszonyaik részvételi-participatív alakítását preferálják. Ezeket összefoglalóan nyer-nyer (nem-zéró összegû́) játszmákra törekvố kultúráknak nevezhetjük.

- Más kultúrák szubjektív érték- és hiedelemvilágára inkább az jellemzô, hogy relatíve kevésbé a kiválóságra törekvố, és azt elismeró értékrendet vallják, rövid távú előnyöket hozó, ́́s mind közva jer,

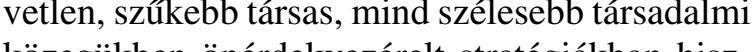
közegukben önén nek, , játszmáik" során természetesnek tekintve a társas viszonyok dôntésekkel való befolyásolásának egyenlő́tlenül megoszló esélyeit. Ezeket a kultúrákat összefoglalóan nyer-veszít (zéróösszegû́) játszmákra törekvố kultúráknak nevezhetjük.

Ha a fó faktorok értelmezésébe a másodlagosan arra töltố bizonytalanságkerülés változót is bekapcsoljuk, a nyer-nyer játszmára törekvő kultúrára inkább a zéróösszegú játszmák kiegyensúlyozott, hosszú távú, kiszámítható mintázata a vonzó, ezzel szemben a nyerveszít keretek között gondolkodó kultúrára jellen nyera játszmájukat körülvevő bizonytalansággal való szembenézés.

\section{2. számú fö faktor: Konzervativ vs. Liberális}

A fő faktorba sorolt kultúraváltozók: nemi egyenlőség (negatív súllyal, azaz a nemi szerepek egyenlôtlenségének tradicionális preferálása) - bizonytalanságkerülés - humánorientáció (negatív súllyal, azaz: nemszolidáris)
A fő faktor a variancia közel 25\%-át magyarázza.

A fó faktor értelmezése:

- Bizonyos kultúrák más kultúrákhoz képest elutasítóbban gondolkodnak a társadalmi szerepek nagyobb átjárhatóságáról, és inkább a biológiai létünk által determinált, természetes nemi szerepeket (munkamegosztást) preferálják, a stabil, kiszámítható társas viszonyokat részesítik előnyben, és a társadalmi szolidaritás alacsonyabb mértékét tartják kívánatosnak a méltányossággal, humánorientáltságoal szemben. Ezeket összefoglalóan konzervatív kultúráknak nevezhetjük

- Más kutúŕk ugyanakkor fontos étéknek tekintik a neni szeepek ájur fontos értéknek tekintik a neni szerepek ájấ dalmi munkamegosztásba való bekapcsolódása során a nagyobb esélyegyenlóséget, nyitottak viszonyaik gyakori megváltozására (bizonytalanságtứrok), es preferaljâk a gondoskodásban, igazságosságban, méltányosságban, önzetlenségben, nagylelkúségben megnyilvánuló társadalmi szolidaritást. Ezeket a kultúrákat összefoglalóan liberálisnak nevezhetjük.

- Ha a fő faktorok értelmezésébe a másodlagosan arra töltố jövőorientáció és hatalmi távolság változókat is bekapcsoljuk, a konzervatív kultúrára jellemző a hatalom egyenlôtlen eloszlásával kapcsolatos relatíve megértóbb viszonyulás és a hosszabb távra való elŏretekintés. Ezzel szas és a libze a liberális kulturúát az egyenlótlenül megoszló ha势 eljövő lehetősségei iránt is nyitott (opciós) gondolkodás jellemzi.

\section{3. számú fö faktor: Rámenốsség/asszertivitás}

A főfaktorba sorolt egyetlen kultúraváltozó a faktor nevét is adó rámenősség/asszertivitás.

A fô faktorra másodlagosan töltő kultúraváltozó: nincs.

fó faktor a variancia $12 \%$-át magyarázza.

A fó faktor értelmezése: azonos az eredeti változóval (ezen a helyen külön nem fejtjük ki).

A társadalmi gyakorlat (leíró) és érték (normativ) változók különbségébồ képzett differenciaváltozók közötti kapcsolat (fó faktorok)

Végezetül képeztem a társadalmi gyakorlat és a társadalmi értékek különbség (differencia) változóit, és erre is elvégeztem a faktoranalízist, amelynek eredményeit a 7. táblázat foglalja össze.

\section{VEZETÉSTUDOMÁNY}


A GLOBE társadalmi gyakorlat (leíró)

és társadalmi érték (normatív)

változóiból képzett különbség (diff) változók faktoranalízisének eredménytáblája - a két fö faktor

\begin{tabular}{|l|c|c|c|c|}
\hline \multirow{2}{*}{} & \multicolumn{2}{|c|}{ Raw } & \multicolumn{2}{c|}{ Rescaled } \\
\cline { 2 - 5 } & \multicolumn{2}{|c|}{ Component } & \multicolumn{2}{c|}{ Component } \\
\cline { 2 - 5 } & 1 & 2 & 1 & 2 \\
\hline Bizonytalanságkerülés_diff & 1,019 & $-0,273$ & 0,935 & $-0,251$ \\
\hline Jövőorientácí́_diff & 0,659 & & 0,903 & \\
\hline Teljesítményorientácí́_diff & 0,335 & 0,228 & 0,561 & 0,382 \\
\hline Hatalmi távolság_diff & $-0,357$ & $-0,301$ & $-0,557$ & $-0,47$ \\
\hline Intzéményi kollektivizmus_diff & 0,537 & 0,418 & 0,655 & 0,51 \\
\hline Csoportkollektivizmus_diff & $-0,417$ & 0,277 & $-0,563$ & 0,374 \\
\hline Humánorientáció_diff & & 0,416 & & 0,692 \\
\hline Rámenósség/Asszertivitás_diff & $-0,096$ & $-0,669$ & $-0,116$ & $-0,81$ \\
\hline Nemi egyenlóség_diff & $-0,098$ & 0,307 & $-0,195$ & 0,609 \\
\hline
\end{tabular}

A 7. táblázatból kitúnik, hogy a kilenc változóból:

- öt változó - a bizonytalanságkerülés, a jövőorientáció, a nemi egyenlőség, a humánorientáció és az asszertivitás/rámenôsség - rendelhetó hozz egyértelmúen valamely faktorhoz,

- négy változó - a teljesítményorientáció, a hatalmi távolság, az intézményi kollektivizmus és a csoportkollektivizmus - ugyanakkor (a „,csak a $>0,25$ feletti faktorsúlyokat vesszük figyelembe" szabályt alapul véve) rendre két faktoron ,ül rajta" (két faktorra töltenek).

A fő szabály (a faktorsúlyok közötti kétszeres különbség) ismét nem segít eldönteni e négy változó tó faktorhoz tartozását, ezért ismét azt az egyszerú szabályt követem, hogy a(z abszolút értékben) nagyobb faktorsúly dönti el a fó faktorhoz tartozást.

A különbség (differencia) változók két fő faktorb rendeződnek.

1. számú fố faktor: A társadalmigyakorlat-változókból képzett Fejlesztésorientáltság vs. Status quo orientáltság fớfaktorok, azzal a kiegészítéssel, hogy a társadalmi gyakorlat fố faktor esetén csak másodlagosan erre a fó komponensre „„ötớ” két kollektivizmus változó (azonos előjellel) most erre a faktorra tölt.

2. számú fő faktor: A társadalmigyakorlat-változókból képzett Versengés vs. Kooperáció és Tekintély vs. Függetlenség sajátos ötvözete. A fó faktor érdekessége, hogy abban a két gender változó (nemi egyenlôség és asszertivitás/rámenősség) egy fớ komponensbe kerül, kiegészülve a humánorientációval.

Alább mind a két fó komponenst (fó faktort) röviden bemutatjuk, a következó egységes szempontrendszer szerint:

- mely GLOBE-változók alkotják a fó faktort,

- mely GLOBE-változók töltenek másodlagosan az adott fó faktorra

- a fő faktor értelmezése, a megnevezés rövid magyarázata.

A fố faktorok magyarázatához szükséges itt rögzíteni a különbségváltozók értelmezését. A különbségváltozó azt jelenti, hogy az észlelt társadalmi gýńtáś́ (esoul (heory-in-

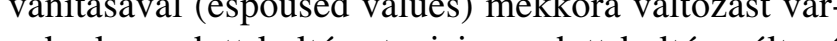
kultúra tagjai az adott kultúraváltozó tekintetében.

\section{1. számú fóf faktor: Posztmodern vs. Modernizá-}

A fô faktorba sorolt kultúraváltozók: bizonytalanságkerülés - jövőorientáció - teljesítményorientáció hatalmi távolság elutasítása (a hatalmi távolság negatív faktorsúllyal) - intézményi kollektivizmus - csoportkollektivizmus (negatív faktorsúllyal).

A fő faktorra másodlagosan töltố kultúraváltozó: incs.

A fó faktor értelmezése: ciós orientáció
Bizonyos kultúrák a bizonytalanság fölötti kontroll növelésére, a jövő elórejelezhetôségének növelésére és a tervezés fokozására növelni igyekszenek a teljesítményorientáltságukat, ugyanakkor csokkenteni a hatalom túlzottan egyenlốtlen elosztását. Erre a kultúrára inkább jellemző a szélesebb társadalmi közegben kooperatív (intézményi kollektivista) stratégiák erôsítése, ugyanakkor a szúkebb közösséghez való kötődés lazítására, a kisközösséghez kapcsolódó lojalitás és büszkeség mérséklésére törekszenek. Ezeket összefoglalóan posztmodern kultúráknak nevezhetjük.

- Más kultúrák

aas kultúrákra inkább jellemzố a bizonytalanságérzet tolerálása, a jövő elôrejelezhetőségének növelésére és a tervezés fokozására és a teljesítményorientáltságuk nôvelésére való mérsékelteb törekvés, megértốbbek a hatalom egyenlőtlen elosztásával. Erre a kultúrára kevésbé jellemző szélesebb társadalmi közegben való kooperatív (intézményi kollektivista) stratégiák erôsítése, ugyanakkor a szúkebb közösséghez való kötődés és a kisközösséghez kapcsolódó lojalitás és büszkeség erősítésére törekszenek. Ezeket a kultúrákat jelenben élö, modernizációs kultúráknak nevezhetjük.

2. számú fö faktor: Nôies vs. Férfias kultúra

A fó faktorba sorolt kultúraváltozók: nemi egyenlóség - asszertivitás/rámenősség (negatív súllyal) - humánorientáció.

A fố faktor értelmezése:

- Bizonyos kultúrák más kultúrákhoz képest kevésbé igyekeznek csökkenteni a társadalmi szerepek átjárhatóságának korlátait, és inkább fenntartani igyekeznek a biológiai létünk által determinált természetes nemi szerepeket (munkamegosztást). Kevésbé igyekeznek csökkenteni továbbá a társadalmi szolidaritás relatíve alacsonyabb mértékét, és kevésbé tôret méltányośg, a húćn n t́́n

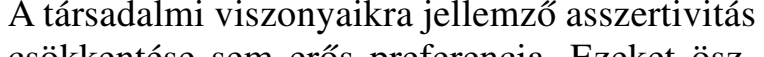
csökkentese sem erôs preferencia. Ezeket öszszefoglalóan férfias (maszkulin) kultúráknak nevezhetjük

Más kultúrák ugyanakkor fontos értéknek tekintik, és növelni igyekeznek a nemi szerepek átjárhatóságát, a nốk társadalmi munkamegosztásba való bekapcsolódása során a nagyobb esélyegyenlőséget, és preferálják a gondoskodásban, igazságosságban, méltányosságban, önzetlenségben, nagylelkúségben megnyilvánuló társadalmi szolidaritás növelését. Erôs preferencia a társadalmi viszonyaikra jellemzố asszertivitás csökkentése is. Ezeket a kultúrákat összefoglalóan nôies (feminin) kultúráknak nevezhetjük.

Ha a fố faktorok értelmezésébe a másodlagosan arra töltó teljesítményorientáció, hatalmi távolság, intézményi kollektivizmus és csoportkollektivizmus változókat is bekapcsoljuk, a nőies kultúrára jellemzóbb a hatalom egyenlótlen eloszlásának mérséklésére való törekvés, valamint a teljesítményorientáció növelése és a mindkét értelemben vett kollektív stratégiák erősítése. Ezzel szemben a férfias kultúrát az egyenlőtlenül megoszló hatalmi struktúrák relatív tolerálása, az elért teljesítményorientációval való relatív elégedettség és a mindkét értelemben vett kollektivizmus esetćben a relatíve önérdekveź́relt stratégí́k preferálása jellemzi.

\section{Jegyzetek}

Cultures are distinctive normative systems consisting of model patterns of shared psychological properties among members of collectivities that result in compelling common affective, generations and that differenciate collectivities from each other. Cultures are distinctive environments of collectivities about which members share meaning and values, resulting in a compelling model pattern of common affective, attitudinal, and behavioral orientation that is transmitted across generations and that differenciate collectivities from each other

A fố faktorok elnevezéseit munkacímként fogalmaztuk meg, ezek a megnevezések még szakmai vita tükrében módosulhatnak. Ugyancsak munkacimeknek tekintendóek, a szakmai viták tükré ben még módosulhatnak.

'Szintén munkacímek, a megnevezések még szakmai viták tükré-

A fó faktorok elnevezéseit munkacímként fogalmaztuk meg, nak. A „Nem-zéró összegứ játszma (nyer-nyer)” és a „,Zéróöszszegú játszma (nyer-veszít)" elnevezéseket a konfliktusstratégiákat bemutató szakirodalmi forrásokból kölcsönöztük, azzal a jelentéstartalommal, amellyel ott használják: „,...a konfliktust olyannak észleljük-e, amelyben csak egymás rovására érhetünk el eredmenyt (ezt szokás nyer/veszít helyzetnek vagy zéróösszegû játszmanak is nevezni), vagy úgy véljük, létezik a helyzetnek egy olyan megoldása, amelybốl mindkét fél elốnyösen jöhet ki (ezt pedig nyer/nyer, vagy nem-zéró összegú játszmának nevez-

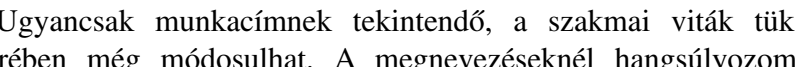
hogy szándékom szerint azok mentesek a mai aktuálpolitikai konnotációktól.

A fő faktorok elnevezéseit munkacímként fogalmaztuk meg, ezek a megnevezések még szakmai vita tükrében módosulhatnak. 


\section{Felhasznált irodalom}

Argyris, C. (1992): On Organizational Learning, Blackwell, Oxford

Bakacsi Gy. (1993): Kísérlet a 80-as évek vezetői magatartási modelljének megfogalmazására. Kandidátusi értekezés, Kézirat

Bakacsi Gy. (1999): The Pendulum Effect: Culture, Transition, Learning. in: Makó, Csaba - Warhurst, Chris (editors): The Management and Organisation of Firm in the Global Context. Institute of Management Education, University of Gödöllő and the Department of Management and Organisation, Budapest University of Economic Sciences, Budapest, p. 111-118.

Bakacsi Gy. (1999): Kultúra és gazda(g)ság - a gazdasági fejlődés és fejlettség és a GLOBE kultúraváltozóinak összefüggései, Vol. 38., Vezetéstudomány, Különszám, p. 35-45.

Cyert, R. - March, J. (1963): A behavioral theory of the firm. Prentice Hall, Englewood Cliffs, NJ

Hall, E.T. - Hall, M.R. (1990): Understanding Cultural Differences. International Press, Yarmouth
Hanges, P.J. - Dickson, M.W. - Sipe, M.T. (2004): Rational for GLOBE Statistical analysis. Societal Rankings and Test of Hypothesis. in: House et al. (2004): Culture, Leadership, and Organizations: The GLOBE Study of 62 Societies, (Vol. 1). Thousand Oaks, CA: Sage, p. 219-221.

House, R.J. - Hanges, P.J. - Javidan, M. - Dorfman, P.W. - Gupta, V. (eds.) (2004.): Culture, Leadership, and Organizations: The GLOBE Study of 62 Societies. (Vol. 1). Sage, Thousand Oaks, CA

House, R.J. - Wright, N.S. - Aditya, R.N. (1997): CrossCultural Research on Organizational Leadership. A Critical Analysis and a Proposed Theory. in: Early, Ch.P. - Erez, M. (editors): New Perspectives on International Industrial/Organizational Psychology (Chapter 20). The New Lexington Press, San Francisco, p. 535-625.

Ronen, S. - Shenkar, O. (1985): Clustering countires on attitudinal dimensions: a review and synthesis. Academy of Management Review, Vol. 10, No. 3.

Cikk beérkezett: 2011. 11. hó

Lektori vélemény alapján véglegesítve: 2012. 1 hó

\section{CALL FOR PAPERS \\ International Journal of Business, Humanities and Technology ISSN 2162-1357 (Print), ISSN 2162-1381 (Online)}

International Journal of Business, Humanities and Technology (IJBHT) is an open access, peer-reviewed and refereed multidisciplinary journal published by Centre for Promoting Ideas (CPI), USA. The objective of IJBHT is to provide a forum for the publication of scientific articles in the fields of business, humanities and technology. In pursuit of this objective the journal not only publishes high quality research papers but also ensures that the published papers achieve broad international credibility.

The journal publishes research papers in the fields of management, business law, public responsibility and ethics, marketing theory and applications, business finance and investment, general business research, business and economics education, international business and economics, tourism and hospitality management, production/operations management, organizational behavior and theory, strategic management policy, social issues and public policy, management organization, statistics and econometrics, personnel and industrial relations, gender studies, cross cultural studies, entrepreneurship development, linguistics, library science, media studies, methodology, philosophy, political science, population Studies, psychology, public administration, sociology, social welfare, technology and Innovation, case studies, management information systems, information technology and so on.
The journal is published both in print and online versions.

IJBHT is indexed with and included in Cabell's, EBSCO, Ulrich's, IndexCopernicus International and Gale. Moreover the journal is under the indexing process with ISI, ERIC, DOAJ, Scopus, and Econlit.

IJBHT publishes original papers, review papers, conceptual framework, analytical and simulation models, case studies, empirical research, technical notes, and book reviews. Special Issues devoted to important topics in business, humanities and technology will occasionally be published.

IJBHT is inviting papers for Vol. 2 No. 2 which is scheduled to be published on March 15, 2012.

Send your manuscript to the editor at editor@ijbhtnet.com,or editor.ijbht@hotmail.com

For more information, visit the official website of the journal www.ijbhtnet.com

With thanks,

Dr. Ronald M. Flower The Chief Editor,

International Journal of Business, Humanities and Technology Contact:editor@ijbhtnet.com 